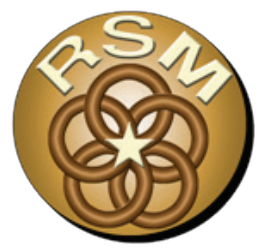

\title{
Regional Sediment Dynamics in Mobile Bay, Alabama; A Sediment Budget Perspective
}

\author{
by Mark R. Byrnes, Jennifer L. Berlinghoff, \\ and Sarah F. Griffee
}

PURPOSE: This U.S. Army Corps of Engineers (USACE) Regional Sediment Management Technical Note (RSM-TN) documents long-term regional sediment transport patterns within Mobile Bay, AL, using multiple bathymetric surveys for the periods 1917-1918, 1984-1987, and 2004-2011 to develop a sediment budget for assessing net changes in seafloor configuration relative to wave and current processes and engineering activities. Although the immediate area of interest is Mobile Bay proper, sediment contributions from the Mobile Bay watershed and shorelines adjacent to the Bay, and sediment exchange with eastern Mississippi Sound through Pass aux Herons and the northern Gulf of Mexico through Mobile Pass, influence the degree to which sediment is deposited within the Bay and redistributed under storm and normal conditions. Documented seafloor changes were used to quantify the flux of sediment within the Bay relative to contributions from the fluvial watershed, adjacent shoreline environments, and from the northern Gulf of Mexico through Mobile Pass. Study results have been used for environmental management purposes related to channel dredging and disposal practice, and water quality and living resources, within the Bay.

BACKGROUND: Mobile Bay estuary is a bell-shaped, submerged river valley system approximately 50 kilometers $(\mathrm{km})$ (31 miles [mi]) long between the estuary mouth at Mobile Pass and the terminus of the Mobile-Tensaw River system, $37 \mathrm{~km}$ (23 mi) wide between Mississippi Sound and the eastern shore of Bon Secour Bay, and approximately $16 \mathrm{~km}$ (10 mi) wide where it meets the Mobile-Tensaw River Delta (Figure 1) (Hummell 1996). The Bay receives water and sediment from the Mobile-Tensaw River system, the nation's fourth largest river system relative to discharge and sixth largest in terms of total drainage area (Isphording and Flowers 1987). The bay encompasses approximately $1,070 \mathrm{~km}^{2}\left(413 \mathrm{mi}^{2}\right)$ of open water (Isphording et al. 1996) and has an average depth of approximately 3 meters $(\mathrm{m})$ (9.7 feet [ft]) at mean high water (Chermock et al. 1974). The entrance, between Mobile Point on the western end of Fort Morgan Peninsula and Pelican Point on the eastern end of Dauphin Island, is an extensive natural inlet with channel depths in excess of $18 \mathrm{~m}(60 \mathrm{ft})$. It is commonly referred to as Mobile Pass and is the primary point of access between Mobile Bay (via the north-south Mobile Ship Channel) and the Gulf of Mexico. The entrance is approximately $5 \mathrm{~km}(3 \mathrm{mi})$ wide. Fort Morgan Peninsula forms the southeastern terminus of Mobile Bay in southern Baldwin County and consists of an extensive beach backed by parallel dunes and numerous sub-parallel beach ridges, formed as a result of net longshore sediment transport processes (Bearden and Hummell 1990; Stone et al. 1992). The east-west Intracoastal Waterway intersects the Mobile Ship Channel just inside the entrance to Mobile Bay (Figure 1). The waterway connects Mississippi Sound with Mobile Bay via Pass aux Herons on the west and traverses east to Perdido Bay via Bon Secour Bay. 


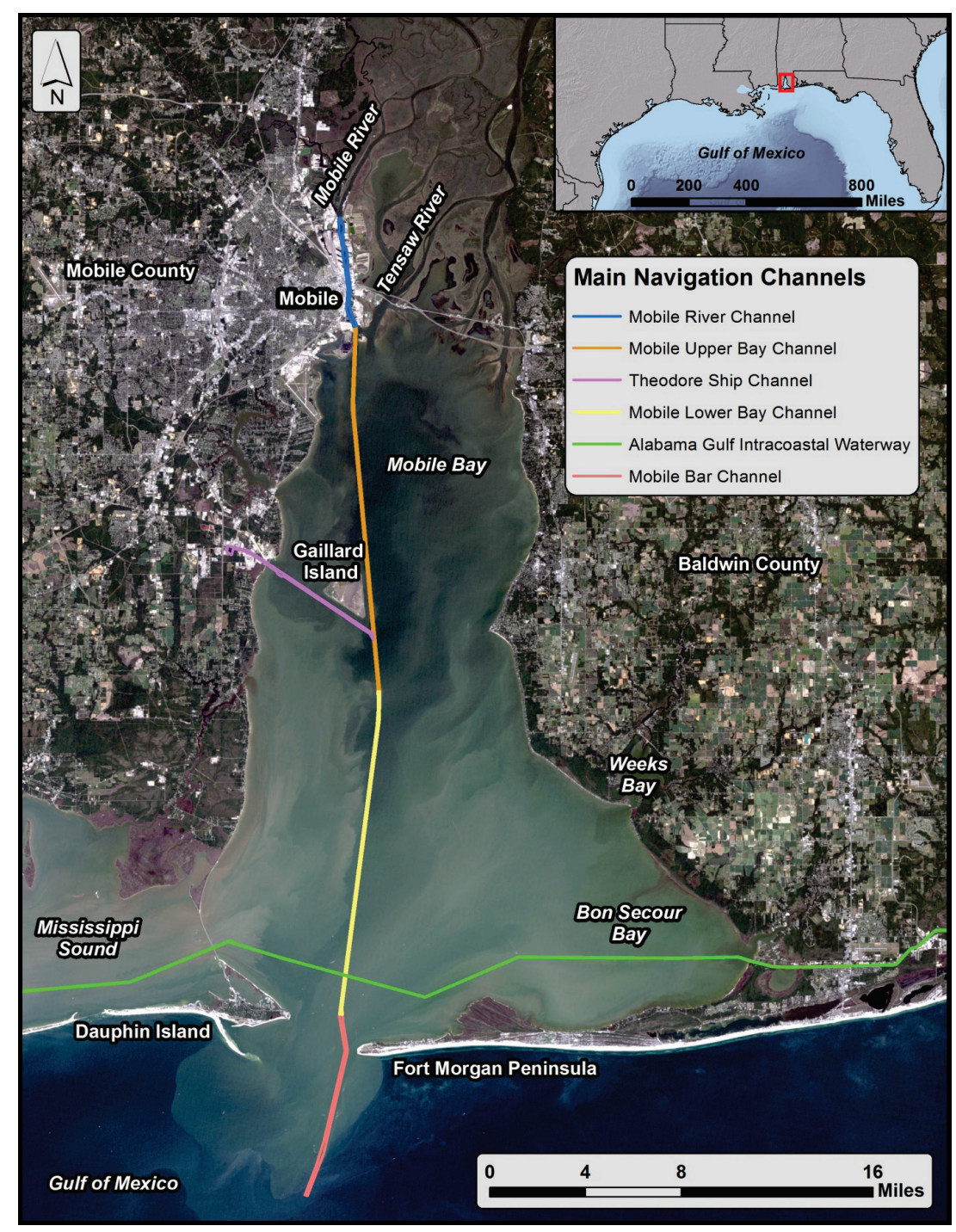

Figure 1. Mobile Bay project area illustrating primary navigation channels. Background Landsat image is from 3 October 2011.

Historical navigation charts indicate Mobile Bay has been shallow since seafloor mapping in the area was initiated, and earliest explorers recognized the importance of this protected open-water estuary for navigation, commerce, and security (Kennedy 1980; McWilliams 1981). As such, navigation channel dredging in Mobile Bay and the Mobile River began with enactment of the River and Harbor Act of 1826. Channel dredging commenced in the northwestern portion of the Bay at Choctaw Pass in 1830, and by 1876, a $5.2 \mathrm{~m}(17 \mathrm{ft})$ deep channel, $60 \mathrm{~m}(200 \mathrm{ft})$ wide at mean low water, was completed from the Mobile River to the $17 \mathrm{ft}$ depth contour in the southern portion of the Bay. Subsequent channel alterations have influenced sedimentation dynamics at and adjacent to the channel, but periodic storm processes are most influential relative to bay sediment infilling and redistribution (Isphording et al. 1989; Schroeder et al. 1998). 
REGIONAL SEDIMENT TRANSPORT DYNAMICS: The most direct method for evaluating regional sediment transport pathways and quantifying long-term net transport for the Mobile Bay estuarine system is to quantify historical change in seafloor morphology with a time series of shoreline and bathymetry surveys. For some coastal areas, survey data are lacking for drawing detailed and confident conclusions regarding bay and nearshore evolution relative to dominant sediment transport pathways and quantities. However, Mobile Bay was surveyed on four separate occasions over a 94-year (yr) period, providing adequate data for documenting bay bottom and nearshore changes, sediment transport pathways, and net transport quantities for determining a sediment budget for the Mobile Bay system.

Shorelines within Mobile Bay have experienced significant changes from natural processes and anthropogenic activities. Winds, waves, tides, currents, and extremes of each resulting from tropical cyclones and winter storms, as well as sediment input, transport variations, and sea level changes, have led to alterations in shoreline position (Byrnes et al. 2013). In the vicinity of Mobile Bay, the majority of wind-driven waves develop from south-southwest winds in spring and summer months and north-northwest winds in winter months (Byrnes et al. 2010). Dredge and fill activities and construction of shoreline structures have also affected the direction and degree to which shorelines change. Coastal land loss resulting from these natural processes and human activities poses a serious problem to not only property owners and infrastructure but also nearshore and coastal habitats such as intertidal, beach, and dune environments, as well as the organisms that inhabit each (Stout et al. 1998).

The western shore of Mobile Bay is characterized by a narrow sandy or marshy shoreline backed primarily by actively eroding coastal plain bluffs ranging from 1.5 to $4.5 \mathrm{~m} \mathrm{(5} \mathrm{to} 15 \mathrm{ft}$ ) high. Dog, Deer, and Fowl Rivers are major tidal tributaries that drain into Mobile Bay from the western shore (Hardin et al. 1976; Scanlan and Wallace 2000; Woods 2006). Shoreline recession along the western margin of Mobile Bay may be attributed to waves generated from winds, uncoordinated shoreline structuring, and local sediment transport processes (Smith 1990). The eastern shore is characterized by beach and marsh environments backed by high bluffs in the north and swamp in the south. Blakeley River and D'Olive Bay, Fish and Magnolia Rivers (both drain into Weeks Bay), and Bon Secour River drain into the eastern side of Mobile Bay (Cook 2007; Cook et al. 2009; Scanlan et al. 2004). Main causes of erosion for the eastern shore are waves, coastal currents, and uncoordinated shoreline structuring (Smith 1990). Erosion control structures, such as bulkheads and revetments, are numerous throughout Mobile Bay. These have increased in number as the coastal population of the region has grown. Structures that were constructed to combat shoreline erosion and protect upland property have led to loss of intertidal habitat and sandy beaches, as well as increased downdrift erosion (Douglass and Pickel 1999).

Although shoreline change patterns (two dimensions) contain a record of the influence of coastal processes on beach response, regional assessment of bay and nearshore morphology (three dimensions) better reveals dominant processes controlling the magnitude and direction of sediment transport throughout a coastal system. Digitized soundings and shorelines were used to create digital elevation models of regional morphology and change for the period 1917-1918 to 1984-2011. Bathymetry data were combined with shoreline data to create a continuous surface from the southern edge of the Mobile-Tensaw Delta and the shoreline of Mobile Bay to the two entrances to the bay: Mobile Pass to the south and Pass aux Herons to the west. The most 
prominent features throughout the study area are navigation channels, deposition at river mouths, and erosion/deposition associated with Mobile Pass.

Natural movement of sediment within the Mobile Bay system is controlled predominantly by water flow and sediment quantity and type supplied by the Mobile Bay watershed, estuarine waves and currents that redistribute bay sediment (primarily those associated with storms), and hydraulics associated with Mobile Pass and Pass aux Herons. Although differences exist between the 1917-1918 and 1960-1962 bathymetric surfaces in specific areas, central bay surfaces away from the navigation channel appear similar. Analytical comparison of bathymetry data yields a difference plot that isolates areas of erosion and deposition for documenting sediment transport patterns and quantifying trends (Figure 2). The most significant changes occurring during this $42 \mathrm{yr}$

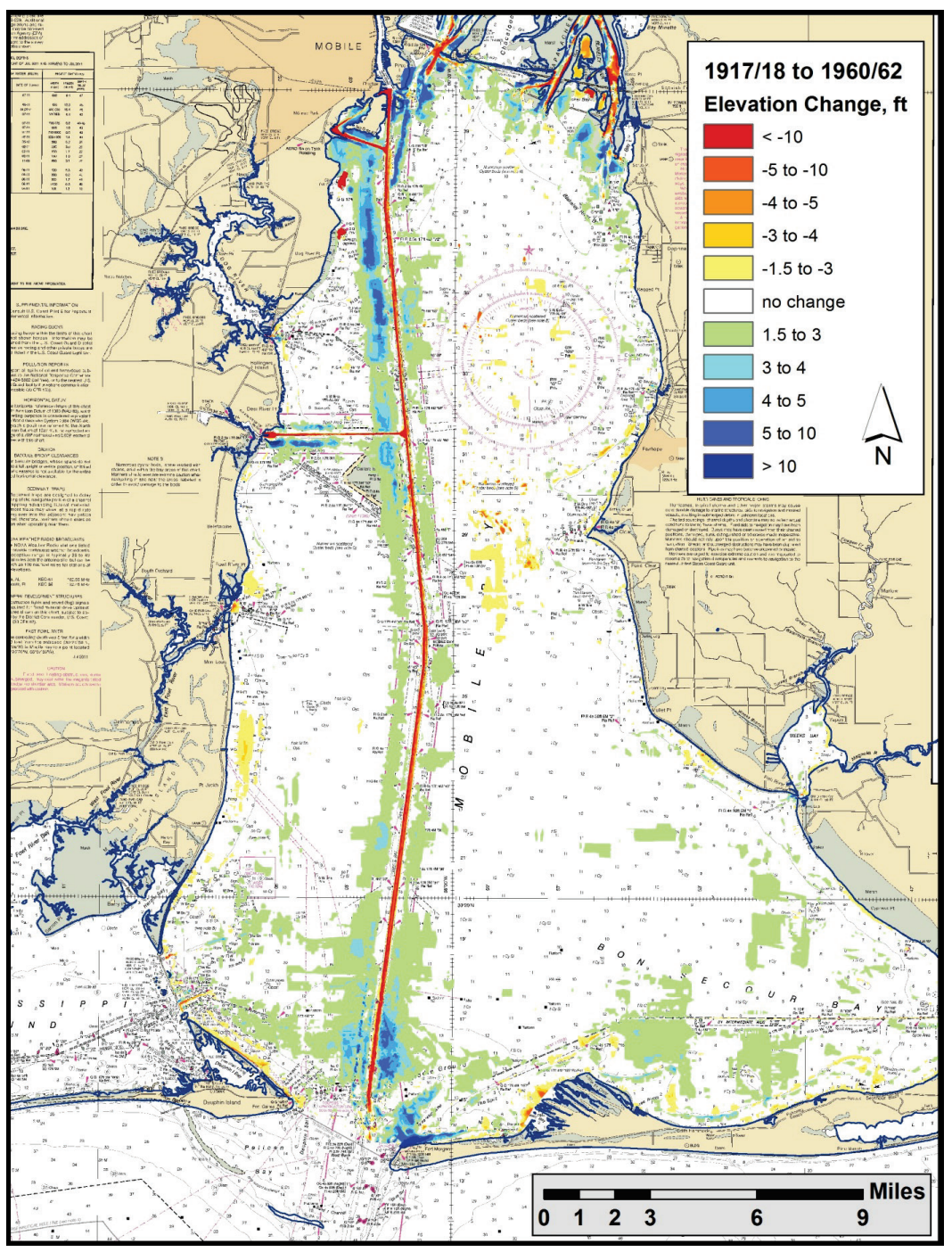

Figure 2. Bathymetric change between 1917 to 1918 and 1960 to 1962 for Mobile Bay superimposed on NOAA chart 11376. Yellow to red colors represent erosion and green to blue colors represent deposition.

interval were associated with deposition in the northern portion of the bay at the mouth of the Mobile-Tensaw Delta (fluvial sedimentation); deposition in the southern part of the bay resulting from current flow and sediment movement at Mobile Pass, including sand transport into Mobile Bay along the north side of Mobile Point; and erosion and deposition associated with navigation channel dredging and placement. Elsewhere in the bay, only minor deposition and erosion were identified within a large estuarine system that is net depositional.

Between 1917 to 1920 and 1984 to 1987, similar patterns of erosion and deposition occurred throughout the bay. Although deposition patterns associated with channel dredging and placement within Mobile Bay are similar for the two change surfaces, the magnitude of change is substantially greater in the northern half of the bay. This does not appear to be the case in the southern half of the bay where sediment from dredged-material placement areas adjacent to the channel has dispersed since 1960-1962. As expected, natural deposition at the mouth of the Mobile-Tensaw Delta continued to supply sediment to northern Mobile Bay in the form of 


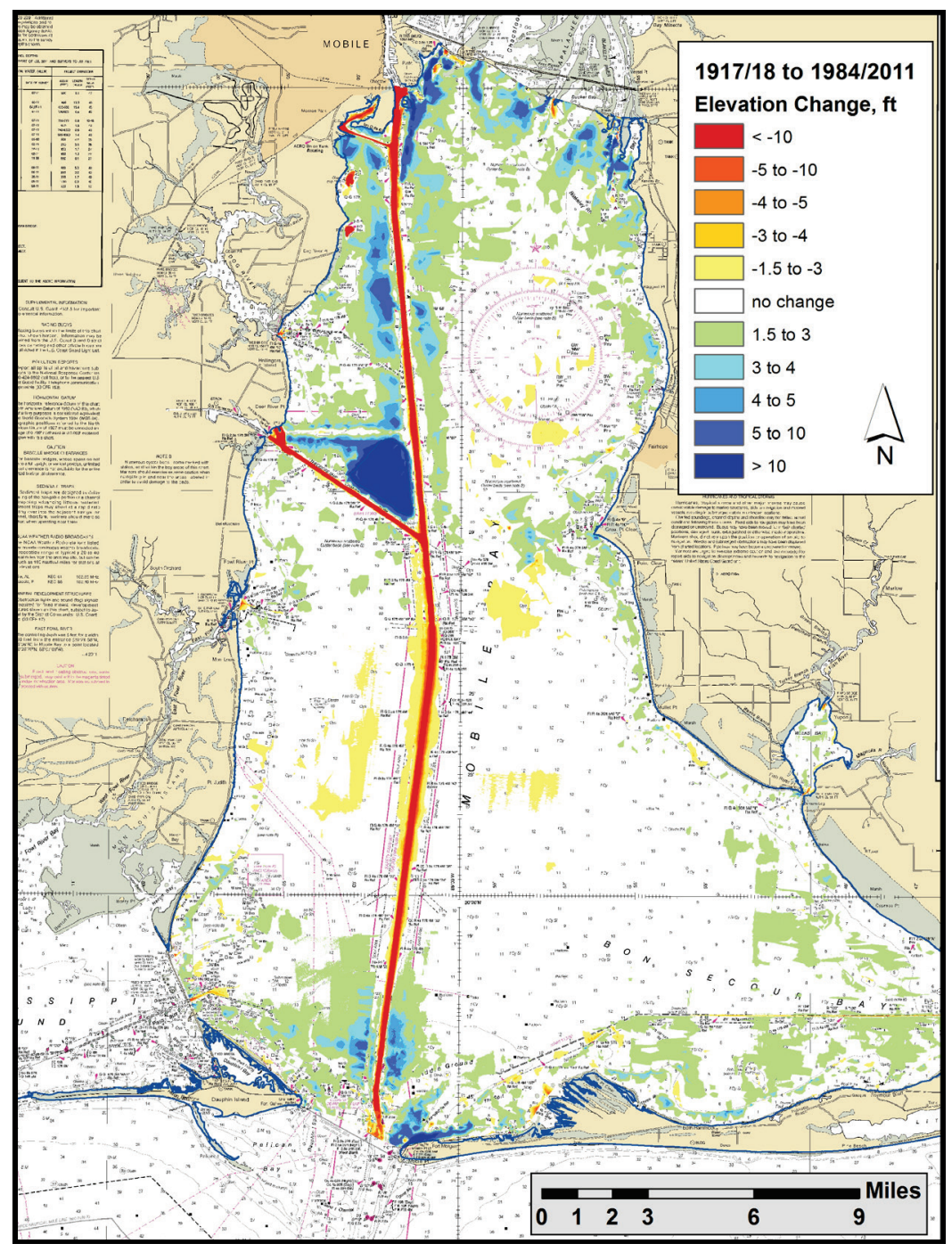

Figure 3. Bathymetric change between 1917 to1918 and 1984 to 2011 for Mobile Bay superimposed on NOAA chart 11376. Yellow to red colors represent erosion and green to blue colors represent deposition. subaqueous deltaic deposits. Cumulative patterns of deposition and erosion within Mobile Bay for the period 1917-1918 to 1984-2011 illustrate similar trends as the previous two surfaces (Figure 3). Deltaic sedimentation at the head of Mobile Bay is consistent for all periods, as is net bay infilling. Channel dredging and placement are very noticeable, but the magnitude of in-bay deposition has decreased with the advent of offshore disposal in the 1980s. Patterns of deposition at Mobile Pass are very consistent for the period of record.

Overall, primary variations in Mobile Bay morphology have been driven by water flow and sediment from the MobileTensaw River system and channel navigation dredging and placement activities throughout the period of record. Similarly, shoreline morphology around the bay has been substantially altered by municipal and residential development; however, human modifications around the bay influence regional morphology far less than channel navigation activities. Given these overall trends, long-term transport patterns are quite predictable and reliable for developing sediment budget estimates.

SEDIMENT BUDGET: Sediment erosion and accretion volumes were quantified for the period 1917-1918 to 1984-2011 by differencing bathymetric survey data constrained by shoreline boundaries (Byrnes et al. 2013). Zones of erosion and accretion were isolated to determine the magnitude of sediment sources and sinks from which a sediment budget was formulated. Overall, Mobile Bay is net depositional (sediment sink), and the Mobile-Tensaw River system is the primary sediment source. The dominant direction of transport is from north to south, and sediment from the Mobile-Tensaw Delta supplies sediment to the bay, the Gulf of Mexico, and Mississippi Sound. Net south-directed transport deposits sediment primarily in the navigation channel with some dispersion of suspended load to the bay east and west of the channel. Historically, most sediment dredged from the channel was placed in bay on either side of the 
channel, transferring sediment toward central portions of the bay. However, dredging records indicate that substantial quantities of dredged sediment are returned to the navigation channel by estuarine circulation processes, resulting in a cyclical sediment removal/placement process (Byrnes et al. 2013).

Sediment erosion and accretion polygons were used to assess net sediment flux throughout the Mobile Bay system. Figure 4 shows the regional (macro-scale) sediment budget for the Bay. The regional budget summarizes details from each of the isolated polygons of erosion and accretion as well as input to the bay from the Mobile-Tensaw River system. White and yellow arrows signify the direction of net sediment movement, and numbers reflect the magnitude of sediment flux in millions of cubic yards per year. Sediment volume change $(\Delta \mathbf{V})$ within Mobile Bay documents net deposition for the period of record. $\mathbf{P}$ is the volume of sediment placed within the bay as a result of maintenance dredging (Rm) and new work (Rn) (Figure 4). As such, if dredged sediment is placed in upland or offshore disposal sites, $\mathbf{P}$ will not equal $\mathbf{R m}$ plus $\mathbf{R n}$. $\mathbf{P}$ is simply dredged material from the channel that is placed in the Bay. As shown in Figure 4, there is a difference between the sum of maintenance and new work dredging $(\mathbf{R m}+\mathbf{R n})$ and $\mathbf{P}$ (5.884 versus 5.614 million cubic yards per year $[\mathrm{mcy} / \mathrm{yr}]$ ), indicating that approximately $0.270 \mathrm{mcy} / \mathrm{yr}$ of sediment was placed offshore and outside the sediment budget control area during the analysis period. It is a component of the $0.547 \mathrm{mcy} / \mathrm{yr}$ that is directed seaward of Mobile Pass.

Analysis of historical survey data indicates that present-day sediment supplied to Mobile Bay is derived primarily from the Mobile-Tensaw River system. Approximately $20 \%$ is deposited at the head of Mobile Bay and remains within approximately $3.2 \mathrm{~km}(2 \mathrm{mi})$ of the northern bay shoreline. The remainder of suspended load is either carried down the Mobile Ship Channel or transported into the bay. New work and maintenance dredging records provided quantities of sediment dredged from the Mobile Ship Channel that were placed in disposal sites in the bay and offshore between 1917 and 2007 (Byrnes et al. 2013). The annualized maintenance dredging rate for the upper channel was approximately $3,376,000 \mathrm{cy} / \mathrm{yr}\left(2,581,000 \mathrm{~m}^{3} / \mathrm{yr}\right)$, and new work was approximately $627,000 \mathrm{cy} / \mathrm{yr}\left(479,000 \mathrm{~m}^{3} / \mathrm{yr}\right)$. The quantity of new work and maintenance dredging placed back in the bay was approximately $3,934,000 \mathrm{cy} / \mathrm{yr}\left(3,008,000 \mathrm{~m}^{3} / \mathrm{yr}\right)$, and $193,000 \mathrm{cy} / \mathrm{yr}$ $\left(148,000 \mathrm{~m}^{3} / \mathrm{yr}\right)$ was placed offshore. Approximately $1,002,000 \mathrm{cy} / \mathrm{yr}\left(766,000 \mathrm{~m}^{3} / \mathrm{yr}\right)$ of maintenance material was extracted from the lower channel, and approximately 589,000 cy/yr $\left(450,000 \mathrm{~m}^{3} / \mathrm{yr}\right)$ was removed as new work. The quantity of new work and maintenance dredging placed back in the bay was approximately $1,218,000 \mathrm{cy} / \mathrm{yr}\left(931,000 \mathrm{~m}^{3} / \mathrm{yr}\right)$ while the amount placed offshore was approximately $364,000 \mathrm{cy} / \mathrm{yr}\left(278,000 \mathrm{~m}^{3} / \mathrm{yr}\right)$. The annual maintenance dredging rate for the Theodore Ship Channel was approximately $82,000 \mathrm{cy} / \mathrm{yr}\left(63,000 \mathrm{~m}^{3} / \mathrm{yr}\right)$, and the annual new work rate was approximately $208,000 \mathrm{cy} / \mathrm{yr}\left(159,000 \mathrm{~m}^{3} / \mathrm{yr}\right)$. All the new work and maintenance dredging $\left(462,000 \mathrm{cy} / \mathrm{yr}\left[353,000 \mathrm{~m}^{3} / \mathrm{yr}\right]\right)$ were placed in the Galliard Island disposal area north of the channel. However, only maintenance dredging quantities can be used for estimating sediment transport rates. Although the exact location for disposal of all channel maintenance dredging is not known, bathymetric changes indicate large areas of deposition just east and west of the Mobile Ship Channel, particularly in the upper bay (Figure 3). 


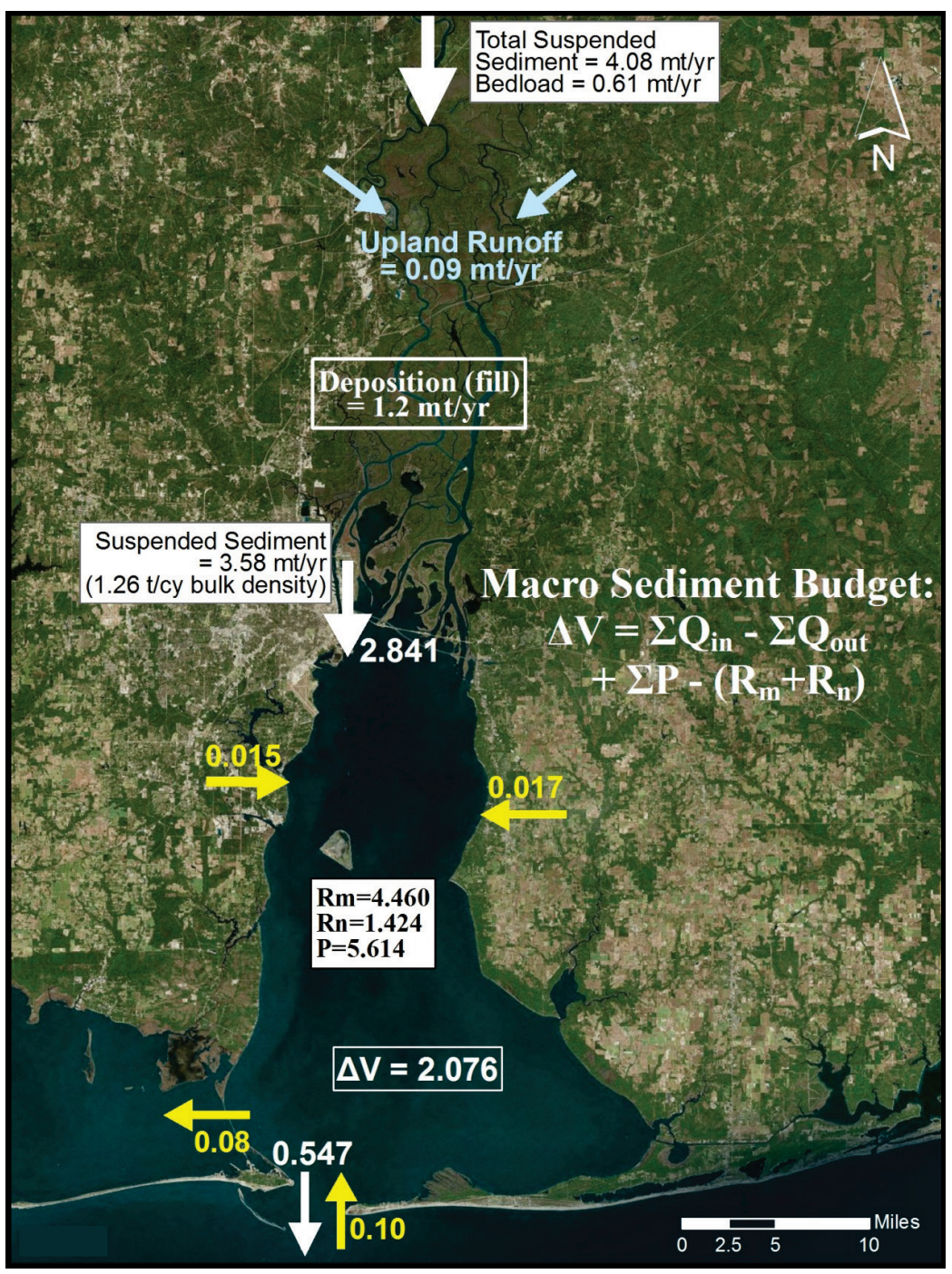

Figure 4. Macro-scale sediment budget for Mobile Bay, 19171918 to 1984-2011. Arrows show the direction of sediment movement throughout the bay, and numbers reflect the magnitude of net sediment transport in millions of cubic yards per year.

Starting at the head of the Mobile-Tensaw Delta, net sediment transport into the delta system is estimated at approximately 4.69 million tons per year ( $\mathrm{mt} / \mathrm{yr})$. This value was determined using sediment characteristics of the Mobile River delta and USGS stream gage data (Isphording et al. 1996). Upland runoff also contributed approximately $0.09 \mathrm{mt} / \mathrm{yr}$ of sediment to the delta, and approximately $1.2 \mathrm{mt} / \mathrm{yr}$ from the watershed is deposited in the delta. The remaining sediment load $(3.58 \mathrm{mt} / \mathrm{yr})$ is the primary source of sediment to the bay and is denoted by the large white arrow at the mouth of the Mobile River. Gailani et al. (2001) determined the bulk density for Mobile Bay dredged material to be approximately 1.26 tons/cy. This bulk density factor was used to convert $3.58 \mathrm{mt} / \mathrm{yr}$ transport to the mouth of the delta to $2.841 \mathrm{mcy} / \mathrm{yr}(2.172 \mathrm{million}$ cubic meters per year $[\mathrm{mcm} / \mathrm{yr}]$ ) for integration with sediment fluxes derived from the 19171918 to 1984-2011 bathymetric change surface. Total annual suspended sediment contribution from watersheds around the margins of the bay was estimated by Isphording et al. (1996) at 
$0.04 \mathrm{mt} / \mathrm{yr}(0.032 \mathrm{mcy} / \mathrm{yr}[0.024 \mathrm{mcm} / \mathrm{yr}])$. Yellow arrows on the east and west sides of the bay represent this contribution to the sediment budget. Approximately $0.547 \mathrm{mcy} / \mathrm{yr}(0.418 \mathrm{mcm} / \mathrm{yr})$ transits Mobile Bay to the Gulf of Mexico, and $0.08 \mathrm{mcy} / \mathrm{yr}(0.061 \mathrm{mcm} / \mathrm{yr})$ is exported to Mississippi Sound. Another $0.10 \mathrm{mcy} / \mathrm{yr}(0.076 \mathrm{mcm} / \mathrm{yr})$ of sand enters the bay from the south. Summing all fluxes into and out of the Bay system results in net sediment accumulation of $2.076 \mathrm{mcy} / \mathrm{yr}(1.587 \mathrm{mcm} / \mathrm{yr})$ within the Bay. Overall, the amount of channel maintenance dredging conducted on an annual basis exceeds the quantity of sediment supplied to the Bay by approximately $1.619 \mathrm{mcy} / \mathrm{yr}(1.238 \mathrm{mcm} / \mathrm{yr})$, suggesting that sediment resuspension within the Bay (most likely along the channel margins where dredged sediment has been placed in the past) contributes significantly to maintenance dredging.

SUMMARY AND RECOMMENDATIONS: Mobile Bay is the second largest estuary in the United States and the primary depositional basin for the sixth largest river system in the United States. The Mobile-Tensaw River Delta at the head of Mobile Bay is the largest inland delta complex in the United States and encompasses a variety of freshwater and estuarine habitats critical to the environmental sustainability of Mobile Bay. Clastic sediment transport within the drainage basin is the primary source of sediment for delta growth at its boundary in northern Mobile Bay, but most fine-grained sediment entering the delta complex travels through the system and into Mobile Bay. Although a significant quantity of sediment enters the Bay from the delta, Isphording et al. (1996) estimated that less than $30 \%$ of sediment eroded from the watershed reaches the Gulf of Mexico. The sediment budget quantities are consistent with this estimate. The general configuration of the Bay, relatively low velocity discharge from the river, and quiescent wave and current conditions within much of the Bay result in significant quantities of fine-grained sediment deposited in the Bay.

Sedimentation in Mobile Bay for the period 1917-1918 to 1984-2011 revealed a pattern of net deposition, except for channel areas. Approximately 2.08 mcy $(1.59 \mathrm{mcm})$ of sediment was deposited in the Bay on an annual basis for the period of record. Sediment input from watersheds surrounding the Bay contributed approximately $2.87 \mathrm{mcy}(2.194 \mathrm{mcm})$ of sediment to the Bay, indicating that approximately $0.79 \mathrm{mcy}(0.60 \mathrm{mcm})$ of sediment was exported annually from the Bay between 1917 to 1918 and 1984 to 2011. Of this quantity, approximately $0.63 \mathrm{mcy} / \mathrm{yr}$ $(0.48 \mathrm{mcm} / \mathrm{yr})$ was transported to the Gulf of Mexico and Mississippi Sound by tidal currents. These quantities indicate that net deposition in the Bay accounts for approximately $72 \%$ of sediment input from watersheds, and $28 \%$ is transported from the Bay through Pass aux Herons and Mobile Pass through natural transport processes and offshore disposal of dredged sediment. Channel maintenance dredging quantities between 1917 to 1918 and 1984 to 2011 exceeded sediment input from Bay watersheds by approximately $1.6 \mathrm{mcy} / \mathrm{yr}(1.22 \mathrm{mcm} / \mathrm{yr})$, suggesting that approximately $36 \%$ of maintenance dredging material placed in the Bay was transported back to the channel.

Net sediment movement within the Bay indicates that in-bay disposal of sediment is most similar to natural long-term depositional processes. Design of dredged material placement techniques that focus on thin-layer disposal farther from the margins of the channels would be beneficial to channel dredging operations and benthic ecology. Dredged material placement farther from the channel may prevent excess maintenance dredging resulting from transport of sediment from channel margin disposal mounds back into the channel. Furthermore, thin-layer disposal 
provides for faster recovery of bay-bottom benthic communities and may have a less permanent impact on benthic ecology.

ADDITIONAL INFORMATION: This U.S. Army Corps of Engineers (USACE) Regional Sediment Management Technical Note (RSM-TN) was produced under the USACE National RSM Program by Dr. Mark R. Byrnes, Ms. Jennifer L. Berlinghoff, and Ms. Sarah F. Griffee, Applied Coastal Research and Engineering. Ms. Linda Lillycrop, U.S. Army Engineer Research and Development Center (ERDC), Coastal and Hydraulics Laboratory (CHL), and Mr. Larry Parson, USACE Mobile District (SAM), funded this research. Questions regarding regional sediment dynamics in Mobile Bay, AL, may be addressed to Dr. Byrnes at mbyrnes@appliedcoastal.com or to Mr. Parson at Larry.E.Parson@usace.army.mil. Additional information pertaining to the USACE National RSM Program can be found at the RSM web site http://rsm.usace.army.mil or by contacting the USACE National RSM Program Manager, Ms. Linda Lillycrop Linda.S.Lillycrop@, usace.army.mil.

This ERDC/TN RSM-17-4 should be cited as follows:

Byrnes, M. R., J. L. Berlinghoff, and S. F. Griffee. 2017. Regional Sediment Dynamics in Mobile Bay, Alabama: A Sediment Budget Perspective. ERDC/TN RSM-17-4. Vicksburg, MS: U.S. Army Engineer Research and Development Center. http://dx.doi.org/10.21079/11681/25970

\section{REFERENCES}

Bearden, B. L., and R. L. Hummell. 1990. Geomorphology of Coastal Sand Dunes, Morgan Peninsula, Baldwin County, Alabama. Circular 150. Tuscaloosa, AL: Geological Survey of Alabama, Energy and Coastal Geology Division.

Byrnes. M. R., S. F. Griffee, and M. S. Osler. 2010. Channel Dredging and Geomorphic Response at and Adjacent to Mobile Pass, Alabama. ERDC/CHL TR-10-8. Vicksburg, MS: U.S. Army Engineer Research and Development Center.

Byrnes, M. R., J. L. Berlinghoff, and S. F. Griffee. 2013. Final Report: Sediment Dynamics in Mobile Bay, Alabama: Development of an Operational Sediment Budget. Mashpee, MA: Applied Coastal Research and Engineering, Inc.

Chermock, R. L., P. A. Boone, and R. L. Lipp. 1974. The Environment of Offshore and Estuarine Alabama. Information Series 51. University, AL: Geological Survey of Alabama, Environmental Division.

Cook, M. R. 2007. Analysis of Sediment Loading Rates and Impacts of Land-Use Change on the D'Olive and Tiawasee Creek Watersheds, Baldwin County, Alabama. Open File Report 0710. Tuscaloosa, AL. Geological Survey of Alabama.

Cook, M. R., N. E. Moss, and D. Murgulet. 2009. Analysis of Sediment Loading Rates for the Magnolia River Watershed, Baldwin County, Alabama. Open File Report 0914. Tuscaloosa, AL. Geological Survey of Alabama.

Douglass, S. L., and B. H. Pickel. 1999. "The Tide Doesn't Go Out Anymore: The Effect of bulkheads on Urban Bay Shorelines." Shore and Beach 67(2-3): 19-25.

Gailani, J. Z., A. Kiehl, J. McNeil, L. Jin, and W. Lick. 2001. Erosion Rates and Bulk Properties of Dredged Sediments from Mobile, Alabama. ERDC TN-DOER-N10. Vicksburg, MS: U.S. Army Engineer Research and Development Center. 
Hardin, J. D., C. D. Sapp, J. L. Emplaincourt, and K. E. Richter. 1975. Shoreline and Bathymetric Changes in the Coastal Area of Alabama: A Remote Sensing Approach. ALA-ADO-X996-CZMP-02. Tuscaloosa, AL: Geological Survey of Alabama.

Hummell, R. L. 1996. Holocene Geologic History of the West Alabama Inner Continental Shelf, Alabama. Circular 189. Tuscaloosa, AL: Geological Survey of Alabama, Environmental Geology Division.

Hummell, R. L., and S. J. Parker. 1995. Holocene Geologic History of Mobile Bay, Alabama. Circular 186. Tuscaloosa, AL: Geological Survey of Alabama.

Isphording, W. C., and G. C. Flowers. 1987. "Mobile Bay: The Right Estuary in the Wrong Place.” In Symposium on the Natural Resources of the Mobile Estuary. Edited by T. A. Lowery. Ocean Springs, MS: Mississippi-Alabama Sea Grant Consortium. MAASGP-87-007, 176-174.

Isphording, W. C., F. D. Imsand, and G. C. Flowers. 1989. "Physical Characteristics and Aging of Gulf Coast Estuaries." Transactions of the Gulf Coast Association of Geological Societies. 39, 387-401.

Isphording, W. C., F. D. Imsand, and R. B. Jackson. 1996. "Fluvial Sediment Characteristics of the Mobile River Delta." Transactions of the Gulf Coast Association of Geological Societies 46: 185-191.

Kennedy, J. M. 1980. Dauphin Island, under French Possession 1699-1763. $2^{\text {nd }}$ ed. Huntsville, AL: Strode Publishers.

McWilliams, R. G., trans. 1981. Iberville's Gulf Journals. Tusacaloosa, AL: University of Alabama Press.

Scanlan, J. A., and R. K. Wallace. 2000. Dog River Watershed Management Plan. Montgomery, AL: Department of Conservation and Natural Resources.

Scanlan, J. A., S. Bodsen, and R. K. Wallace. 2004. Final Draft: Bon Secour River Watershed Management Plan. Montgomery, AL: Department of Conservation and Natural Resources.

Schroeder, W. W., J. L. W. Cowan, J. R. Pennock, S. A. Luker, and W. J. Wiseman. 1998. "Response of Resource Excavations in Mobile Bay, Alabama, to Extreme Forcing." Estuaries 21(4A): 652-657.

Smith, E. 1990. "Regimes Contributory to Progressive Loss of Alabama Coastal Shoreline and Wetlands." Gulf Coast Association of Geological Societies Transactions 40: 793-796.

Stone, G. W., F. W. Stapor, J. P. May, and J. P. Morgan. 1992. "Multiple Sediment Sources and a Cellular, Non-Integrated, Longshore Drift System: Northwest Florida and Southeast Alabama Coast, USA." Marine Geology 105(1-4): 141-154.

Stout, J. P., K. L. Heck, J. F. Valentine, S. J. Dunn, and P. M. Spitzer. 1998. Preliminary Characterization of Habitat Loss. Mobile Bay National Estuary Program. Dauphin Island, AL: Dauphin Island Sea Lab.

Woods, P. S. 2006. A Study of the Fowl River Sub-Watershed. Mobile, AL: Alabama Department of Environmental Management.

NOTE: The contents of this technical note are not to be used for advertising, publication, or promotional purposes. Citation of trade names does not constitute an official endorsement or approval of the use of such products. 